\title{
Voices of the Commonwealth: An Oral History of the Modern Commonwealth 1965-2012
}

\section{Sue Onslow}

To cite this article: Sue Onslow (2017) Voices of the Commonwealth: An Oral History of the Modern Commonwealth 1965-2012, The Round Table, 106:1, 47-59, DOI: 10.1080/00358533.2016.1272958

To link to this article: $\mathrm{http}: / / d x . d o i . o r g / 10.1080 / 00358533.2016 .1272958$

册Published online: 17 Feb 2017.

Submit your article to this journal

Џll Article views: 3

Q View related articles $\circlearrowright$

View Crossmark data $\$ 


\title{
Voices of the Commonwealth: An Oral History of the Modern Commonwealth 1965-2012
}

\author{
Sue Onslow \\ University of London, London, UK
}

\begin{abstract}
This article describes a major exercise undertaken by the Institute of Commonwealth Studies, London, to put together an oral history of the modern Commonwealth. The project was set in the context of a wider research agenda aimed at investigating whether the Commonwealth has made any difference globally in policy terms. As part of the exercise, the author, who was the lead researcher on the project, interviewed senior figures within the Commonwealth who played key roles in shaping the destiny of the organization and in influencing policy. The article is a personal account of the exercise.
\end{abstract}

\section{KEY WORDS}

Commonwealth; Shridath (Sonny) Ramphal; Malcolm Fraser; Mahathir Mohamed; $P$. J. Patterson; Commonwealth Heads of Government Meeting; Margaret Thatcher; Marlborough House

\section{Introduction}

The Institute of Commonwealth Studies has now concluded its major oral history project, 'An Oral History of the Modern Commonwealth since 1965', comprising extended interviews with over 65 Commonwealth leaders, diplomats, civil servants and journalists across the 50 -year time span since the creation of the Commonwealth Secretariat. The overall research question for the project was designed to look at the Commonwealth as a diplomatic actor since 1965: 'Has the Commonwealth made a policy difference-and if so, how-since 1965?', and to assess the findings on the basis 'Does the Commonwealth's record of achievement justify continued engagement with the association?' I acted as the project's lead interviewer and have conducted over 90 interviews over the past three years. This library of recollections, reflections and opinion on the Commonwealth as a diplomatic actor is now freely available and fully searchable on a designated website, www.commonwealthoralhistories. org, hosted by the Institute.

The editor of The Round Table has asked me to give my personal account of these interviews, rather than an academic interpretation clouded by theory or emphasizing methodology. (I shall merely state I used a semi-structured interviewing technique to do these elite interviews.) Let me say, first and foremost, doing this project was an enormous privilege. Talking to people across the world who rose to the height of political power and who have genuinely made a difference? As my teenagers would say, 'What was not to like?' I have travelled the globe, visited Commonwealth cities I never dreamed of seeing (such

CONTACT Sue Onslow sue.onslow@sas.ac.uk

The project 'An Oral History of the Modern Commonwealth 1965-2010' was funded by the Arts and Humanities Research Council (AH/J006548/1). Interviews for 'An Oral History of the modern Commonwealth 1965-2012' are available at www.commonwealthoralhistories.org 
as Georgetown, Guyana, and its charming old colonial architecture, or revisiting Suva in Fiji). I have met and interviewed people who are political legends-such as Dr Mahathir Mohamed, Malcolm Fraser and P. J. Patterson-and renewed personal connections, with Sir Shridath 'Sonny' Ramphal, whom I first interviewed in 2006, and with old friends, such as David MacDowell whom I knew as the New Zealand High Commissioner when I lived in Fiji some 35 years ago. I cannot lie: the past three years have been enormously stimulating and enjoyable.

Right from the start of the interviews, I was determined I would not be a female Jeremy Paxman. I firmly believe being an aggressive or confrontational interviewer is fundamentally counterproductive. There is an old saying: 'Honey catches more flies than vinegar'. Second, the research focus was firmly on 'the Commonwealth as a diplomatic actor'. This was subtly and importantly different from 'What did the Commonwealth do?' The research questions of the project were directly connected to the interview cohort: whom should I interview? Everyone to whom I spoke had recommendations-indeed, everyone had a different list of 60 people. As a project, we had to be selective and, given the time span and range of issues, inevitably there are considerable gaps in the project's coverage. Furthermore, funds were limited. Persuading former Commonwealth political leaders, many of whom are still very busy, as well as organizing the necessary travel, doing interviews and clearing the transcripts - the whole process took an enormous amount of time. It was very far from a 'journo' approach of 'quick and dirty'.

Also, despite our best efforts to ensure that we had chronological (1965-2012), thematic, institutional and geographic coverage across the vast, sprawling association which is the Commonwealth - and Richard Bourne, as Chair of our Advisory Board, understands this better than most-most of the people I talked to were men. This is a reflection of maledominated, hierarchical, political and institutional appointments of the era, although mercifully the gender shift was increasingly apparent by the 1990s. And they were powerful men, used to being interviewed and dealing with the media, attentive to the power of rhetoric and the importance of words, jealous of their contribution to their country's history and the view of posterity, and who very often had written their memoirs and laid down a certain narrative: it has been called the 'song of self'. This makes for highly conscious behaviour, to continue to polish their place in history. I was asked a couple of times, did this not make me particularly at the mercy of their crafted - and not necessarily accurate-version of events? The process of memory what and recall is notorious for the associated progressive sanding of the contours of memory of what actually happened. Were they not going to regard me rather like a cushion, plonking themselves heavily on the interview so as to leave an indelible imprint on my view of events, and their particular contribution? I decided to turn that directly to advantage, i.e. to try to give people sufficient space to lay out their recollection and version of past happenings, which I could to try to explore further or to probe where I could, using triangulation by checking with other contemporary actors. However, since I frequently did not have access to the original records to check, I was inherently limited in my ability to call them to account. That said, I was not out to trip them up. Also, not knowing at the start the 'deep' history of the Commonwealth meant I was learning constantly the 'what' as well as impelled to ask the 'why', the 'how' and the 'if not, why not?' In fact, a lack of knowledge can be an invaluable tool in a research project, as it promotes curiosity and an enquiring spirit to 'understand the causes of things'. 
There is also an important point on when is the best time to interview such powerful people? How best to judge the moment-between fighting current but receding battles and accurate recall, with the licence to speak freely that can come with greater separation from responsibility? I came to the conclusion 5-10 years after leaving post was possibly the optimum time, when recollection of policy content and the diplomatic process was still relatively fresh and the burdens of discretion required of office were easing-but there were so many exceptions! Each interview is historically contingent, influenced by context and interaction between each speaker. Gender was an ever-present aspect in these encounters. In addition, these interviews took place over three years, across the spectacular 'own goal' of the Colombo summit. It was far from a comfortable time for the Commonwealth 'family'.

\section{So What Did I Try and Do?}

Read everything the interviewee had written-memoirs, autobiographies, past interviews, as well as biographies and summaries of national histories.

Submit a short list of questions that were tailored particularly to each person's experiencebut which had to bear in mind the agreed research questions of the project. This could be something of a challenge if the person I was talking to had a dim view of the Commonwealth (my interview with Dr Mahathir immediately comes to mind), or if the association came low down on the list of that country's foreign policy priorities. Also, what to do if what I deemed to be important no longer featured at all in their memory? Flora MacDonald, former Canadian Foreign Minister, had very little recollection of the Lusaka Commonwealth Heads of Government Meeting (CHOGM) - except that she was supremely irritated by Mrs Thatcher whom she felt flirted outrageously with African leaders. She was much keener to tell me about Canada's involvement in the US hostage crisis in Tehran in 1979-80, and her sense of achievement on scaling the foothills of Mount Everest.

Read the national daily newspapers before the interview itself. Reading the news gave me an understanding of the background context and the political/cultural way of thinking that surround an interview.

Talk to taxi drivers on the way there, and back - an invariably good source for the pulse of popular thinking.

Listen intently and intelligently, to get the interviewees to relax and engage. There was invariably a degree of them interviewing me first. They were not trying to impress me, as I have seen time and again with former powerful people and younger interviewers, but my role was to show that I knew what I was talking about, that I was not intimidated, and genuinely wanted to know more-on behalf of others who would use this material. (At times it felt like having a small, portly but invisible parrot bobbing up and down on my shoulder, hissing, 'Other Questions for Other People!') Unfortunately, Secretary General Kamalesh Sharma did not agree to my application to see archives held at Marlborough House on the period post-1983 (with the exception of the material associated with the Nassau CHOGM, the first Eminent Persons Group (EPG) and the subsequent London mini-summit, as this had already been granted to Stuart Mole).

The explanation for this refusal was the Secretariat operates a formal 30-year rule of release. This posed immediate problems as the political files held at the Secretariat were, and are, much more comprehensive than those dealing with economic and development matters, and meant I could not brief myself thoroughly with the necessary contemporary 
background diplomatic material and policy discussions; nor could I use these to prompt detailed recollection from the interviewees. Furthermore, my Freedom of Information (FOI) applications to the Foreign and Commonwealth Office (FCO) had to be submitted singly, the FCO were extremely slow in responding, and the resulting papers were largely uninformative because of current departmental redactions. Therefore, in the interviews covering events from the mid-1980s, I did not have original documents to work from, and could not get the interviewee to engage directly with contemporary policy discussions-not just what they might remember. This depressingly negative attitude by the FCO underlined that FOI legislation is more useful to investigative journalists than historians, as well as symptomatic of the pressures of staff cuts across Whitehall, the small size of the Commonwealth division within the FCO - itself an indicator of the lowly importance attached to the associationand hypersensitivity of current staff to releasing any archival material that might be deemed to impinge on current international relations. As Matthew Neuhaus pointed out, the irony is that in the Commonwealth Secretariat until the mid-2000s, classification of material did not exist: a limited number of current political files were recognized as sensitive, and handled accordingly; otherwise, material was unclassified.

I cannot say every interview was a pleasure. In fact, I came out of my interview with Bob Hawke fuming. By contrast, interviewing women for this project was a complete delight: these proved to be 'interview by conversation' and engagement, rather than interview by interrogation. Given, as I say, the climate of the times, it highlighted that the women leaders of the Commonwealth across this 50 -year span have been truly exceptional.

Getting the cleared transcripts back could be a protracted tussle. The interviews were intended to be on the record, but there were exasperating redactions when they came to see the draft transcript. I tried to persuade people to reconsider and to close certain passages for a set amount of time, rather than strike them from the record completely. I was not always successful. Furthermore, on too many occasions, people fiddled with their prose-crafting what they wanted to say, rather than what they had actually said. As powerful men, accustomed to staff, many of them treated the interview transcript as the first draft of a speech by an underling.

\section{Relevance}

How are all these interviews relevant to the Commonwealth of today? This library of transcripts is an extraordinary snapshot on the Commonwealth's institutional memory. A community of memory is vital to any group's vitality and sense of identity-a shifting sense of history, cultural communion, shared struggle, resistance and rejection. The Commonwealth encapsulates transnational and fluid claims of solidarity, with sufficient constants to deny contemporary constructs of the demands of organizational 'hard power'. The Commonwealth is a quintessential 'soft power' association, at its best 'smart power'. As an idea-of shared heritage, common language, norms and forms, as a 'values-based' association of 53 sovereign states-it does not quite make sense in today's rapidly changing, hard-power wired world; but then again, as an idea, the notion of 'Europe' is blowing apart at the seams under the strain of immigration and accelerating global social change. Ironically, as a more flexible and amorphous association, the Commonwealth could prove more robust than the current hard-power organization of Europe of the 28 . 
Taken together, these interviews give a unique insight into the inner workings of the Commonwealth, as well as the importance and subtleties of the meaning of 'the Commonwealth' to different people, at different times and different places. It really comes across as a faith, a mantra, a tent-without sides, a post-colonial shape-shifter, a hybrid allowing for multiple identities and ideas. This very fluid identity is the essence of its inner strength-witness those African leaders who warmed to Moses Anafu as a Commonwealth diplomat because of his Nkrumah-ist beliefs. Since the 1990s it has also suffered from a 'brand problem'-more on that later. Inevitably perhaps, there is a considerable amount of material and comment in the interviews on apartheid South Africa (which is my own area of research strength), and the varying and combined Commonwealth actions and activities to combat this. There are new insights into the Commonwealth's diplomacy and supportparticularly Max Gaylard and Moses Anafu who are brave men indeed-for South African transition post Mandela's release, in what can only be described as a low-intensity war.

Mandela was not very up-to-date with the world when he came out of prison. When I was in Natal, Mandela called me into his office, and he used to call me 'Mos'. He said, 'Mos, this is the heart of the violence [between the ANC and Inkatha Freedom Party Supporters]. What is happening [here] is going to ruin everything that my generation has lived and worked for ... You go and talk to him [Buthelezi]. You, somebody from the UN, and somebody from the OAU: the representatives of the international community.' So, I asked him, 'Madiba ... we are the international community, as you've enumerated. But we speak with different accents. A Commonwealth representative knows what the Commonwealth position is on this issue. The EU, for example-Mrs Thatcher has a representative there, right? Now, if you send a mixed delegation representing the international community there, the message won't be as sharp as sending one person.' He said, 'Okay, then you alone should go.' So, I went. (Moses Anafu, Political Affairs Division, Commonwealth Secretariat)

Although so much of the Commonwealth's public energies were devoted to securing economic sanctions and the sports boycott, in the view of the Australian Foreign Minister, the real story lay with the Commonwealth and financial sanctions:

At the leaders' meeting [the 1987 CHOGM], Bob Hawke undertook to do a study of the impact of financial sanctions on South Africa. He designated a particular treasury official, Tony Cole, to lead the project, and we not only did the study but turned it into a Penguin special book ... called Apartheid and International Finance. This had actually quite a major influence in the worldwide debate - not just within the Commonwealth, but within all the financial centres and within the Unites States in particular ... Everyone remembers the trade sanctions which went back years before. Everyone remembers the sports boycott, the cultural boycotts and so on. But it was the financial sanctions that only really started to come on after 1988/89 that mattered, and the Commonwealth actually led the way. (Gareth Evans, Australian Foreign Minister)

Unsurprisingly, Mrs Thatcher comes in for considerable stick. Recollecting Mrs Thatcher's arrival at the Kuala Lumpur CHOGM with the release of African National Congress (ANC) activist Walter Sisulu 'in her pocket' and arguing that South Africa deserved international support in its process of reform,

Well, this was the usual nonsense that one had from the Brits. It may well have been well-intentioned nonsense in the case of [British Ambassador to South Africa 1987-91, Robin] Renwick, but it was no less nonsense for that ... It wasn't just a matter of releasing [Walter] Sisulu. It was a matter of releasing Mandela, it was a matter of getting into a full-scale transition to democracy, and small gestures were not enough. No, it was time for an absolutely major squeeze, and it was just the usual defensive nonsense that we had from the Brits on that. (Gareth Evans) 
Second, having interviewed key members within the South African Department of Foreign Affairs (including 'Pik' Botha, the South African Foreign Minister), what comes through very clearly is the importance of Thatcher as a bridge-builder in the 1980s. The National Party leadership did not trust the US, but Thatcher-who was consistently sending messages to the obdurate South African president (she was much more in tune with FCO thinking than she cared to admit in her memoirs) - was valued and deemed enormously useful as the National Party tried to find itself out of its corner.

There are two leaders who played a significant role in getting apartheid removed peacefully: Margaret Thatcher and Ronald Reagan. The others made it more difficult for us. Every time I was trying to further the repeal of some act embodying apartheid, the opposition I had to deal with within the National Party reproachfully reacted as a result of the negative [attention] internationally ... These were the two leaders who were nonetheless impressed by what the rest of the world considered face-saving minor changes. And they made it clear that they were opposed to violence as the force of change in South Africa ... I was pointing out to our caucus that we cannot insult these two. We cannot insult Margaret Thatcher. She is opposed to severe economic sanctions. I used this as a bargaining chip, a crowbar, in order to move faster towards dismantling apartheid. (R. F. 'Pik' Botha, South African Foreign Minister 1977-90)

[Letters between Thatcher and Botha were] written in English. I'd be given an oral outline in Afrikaans. I'd go and write it in English. Then give Pik the draft; he might play with it a bit. Those were the days before laptops and all that sort of thing ... We would send the draft over and it would come back with PW's signature, but with some alterations. This caught Pik in a very difficult situation because he had no choice but to send the letter as approved and signed by PW Botha. But he did not want it to be misunderstood when it arrived at the other end. So he would say to the ambassador, 'Look, there are letters coming, but please here's the actual draft.' [The Prime Minister would get] an oral interpretation of what the actual message was intended to be ... because someone like PW Botha would think in Afrikaans and his staff would translate it into his English, which on occasion was almost incomprehensible, you didn't understand what he was saying. You could easily read it the wrong way, or it could be ambiguous and Pik had specifically not wanted that formulation, but he had no choice. So he had to send a letter, it had to go to the British Prime Minster, but he was saying, 'Oh, my God, you know, when it lands on her desk what on earth is she going to think?' So he had to find a way to deflect the problem: to take the thorn out of the message ...

S. O. [Interviewer]: This was officials [in the South African Department of Foreign Affairs and No. 10/the Foreign and Commonwealth Office] talking (to each other), not leaders talking to leaders, because Mrs. Thatcher's letters were drafted by her key advisor, Charles Powell. So actually you were communicating with Charles Powell!

That's right, absolutely ... So we did have to have the back channel. (Victor Zazeraj, South African Department of Foreign Affairs)

So-and I say this strongly, as it is an uncomfortable and indeed unwelcome conclusion for the liberal left within the Commonwealth, Thatcher was an effective Commonwealth asset in the international struggle against apartheid. Her press conferences were certainly disastrous from the point of view of presentation, her treatment of Foreign Secretary Geoffrey Howe inexcusable, but in the story of the Commonwealth and ending apartheid, Thatcher is at the heart. That begs the question, why did she not tell the inner circle of Sir Sonny Ramphal and heads of her prime ministerial missives to P. W. Botha? Or do a better job persuading other Commonwealth heads of her consistent opposition to racism? Thatcher's response to de Klerk parallels her earlier identification of Mikhail Gorbachev as an opponent 'to do business with'. And she was far less out of line with Foreign Office thinking than she liked 
to present. Was it 'trust only went so far'? I suggest no country's leader told, or tells, all its foreign policy secrets and links at the Retreats. Also, would all other Commonwealth leaders have listened? I suggest, 'no'. Associated with this, what comes through powerfully was the ease and relief in the Commonwealth when John Major was prime minister-and that feeling was mutual across Whitehall.

I have given details here of the Commonwealth and its contribution to the sustained struggle against apartheid, described by Professor James Mayall as the Commonwealth's 'grand strategy'. However, there is a great deal on Commonwealth diplomacy and conflict mediation in these interviews on other areas of diplomatic activity. One issue that came up from a multitude of angles was the US invasion of Grenada. Doing interviews in the Caribbean with Sir Sonny, Sir Ron Sanders, Dame Billie Miller, Edward Seaga and Rashleigh Jackson-as well as reading reports in the Starbraek News about the Commission of Enquiry into Walter Rodney's assassination-gave me a much clearer understanding of the regional context of the Cold War and small state perceptions. Mrs Thatcher came out of this rather better than perhaps her detractors would like-in fact, if the information in the Thatcher archive is used together with these interviews and the Commonwealth heads' meetings' records, it highlights the seriousness and prior preparation of the British prime minister for Commonwealth meetings, and the audio recording of her telephone conversation with President Ronald Reagan demonstrates that her anger at not having prior warning of the impending US military action against a Commonwealth country was not feigned-as Sir Ron claimed.

\section{Fiji}

The crisis around the coups in Fiji in 1987 features-the 'coups, coups, many coups'. Ambassador Kaliopate Tavola recalled ruefully his personal amazement at the news from Suva, and that when he came down to breakfast at the Commonwealth Agricultural Organization meeting, he was greeted by African colleagues with the words 'Welcome to the club!' As Philip Murphy mentioned at the launch of the project in October, the Queen took a more active role in Fijis suspension at the Vancouver CHOGM in 1987 than is commonly recognized:

[O]ne of the features of the Commonwealth Heads of Government Meetings was [that] she would have a meeting with each of them. You'd have an allotted time. So, my time was allotted and I went there. Before I went in, I saw the private secretary, Bill Heseltine. He had been at university with me, at the University of Western Australia. I knew him well, and I told him that I thought the way the Commonwealth meeting seemed to be scheduled to go about Fiji was very weak. It recognized the fact that the Queen's representative had been thrown out. And he said, 'Will you talk to her about it?' And I said, 'I will' ... So, I put to her directly my concern that the proposed draft was very weak and that it should be strengthened, and she said, 'I agree with you.' And she intervened and talked to a lot of people and the thing was changed as a result of her intervention. So, she was, in the Commonwealth, much more than just a figurehead. (Bob Hawke, Prime Minister of Australia)

There are other historic events on which interviewees made comments from their varying perspectives: the role of attempted Commonwealth mediation in the Nigerian war (there is a considerable amount in Arnold Smith's personal papers); the importance of Arnold Smith in promoting international recognition of Bangladesh's independence, stemming directly from his horror at the Biafran humanitarian disaster; and how Nigeria in particular was 
persuaded to accept Bangladesh's 'secession'. (The Bangladesh president used the Ottawa Retreat to obtain Australian support for Bangladesh's bid for international recognition in the United Nations Organization). The idea of trying to broker a settlement between the Tamil Tigers and the Sri Lankan government unfortunately came to nothing. All steered clear of commenting on whether the Commonwealth could assist in Indian-Pakistan negotiations on Kashmir.

The interlocking themes of Zimbabwe and the Commonwealth are very strong. I would like to say two things coming out of these interviews: first, on the Commonwealth's contribution to eventual Zimbabwean independence in 1980; and second, on Zimbabwe's abrupt departure in 2003.

In Commonwealth annuals, the Lusaka CHOGM has achieved almost mythical status as a triumph of Commonwealth coordinated diplomacy. I have not only captured Sir Sonny's views but also, thanks to Clyde Sanger, got a worker bee's eye view of the considerable challenges of organizing a heads meeting in an African developing country, and frontline state in the deepening conflict in neighbouring Rhodesia. The Thatcher government had clearly tried to use the Queen's attendance as a card to get Joshua Nkomo's Zimbabwe People's Revolutionary Army (ZIPRA) fighters to declare a ceasefire. Ramphal later helped broker that. But the interviews-particularly my discussion with Mark Chona (which I am in the process of clearing with him) - and available records challenge the idea that it was the meeting in Kenneth Kaunda's study that 'turned the trick' of the UK agreeing to an all-party conference. If you compare Commonwealth perceptions with the archives at Kew, Thatcher and Carrington had already agreed to this before they left for Lusaka. Chona comments on their 'body language' on the eve of the meeting, which gave him a considerable clue. I am not minimizing the importance of Ramphal's prior diplomacy and choreography of the summit in presenting a crucially Commonwealth united front-especially important since the Patriotic Front did not sign the Lusaka accord or agree to negotiations in London-or the importance of publicity and imagery. But these interviews help to temper the myth that has emerged.

The interviews also highlight the-to my mind-shameful silence by Britain, the Commonwealth, the Secretariat and the Secretary General on the spiral of violence which emerged in Matabeleland in Zimbabwe between 1982 and 1987. Frankly, when I asked Sir Sonny Ramphal about this directly, his answer bordered on the incoherent- 'well, the ANC was silent'. It strongly suggests Marlborough House's liaison with the ANC in Lusaka-that they do nothing which might antagonize Prime Minister Mugabe-but I could not confirm this. Hugh Craft, head of International Affairs at the time, did not respond when I emailed him to ask about this - this was after we had had a three-and-a-half-hour interview. Moses Anafu came up with the frankest reflection:

What we didn't know at the time-even now, we still don't know, I'm sure-- was how much was South Africa involved in it, really. And we didn't know who else might have been involved. I don't know how to put this to you. Countries freshly arrived at independence tend to be very prickly, and you have to be very careful who you speak to. Because not too long ago, they were refugees; today, they are a sovereign government. You have to find a way of speaking to them and getting things across to them. I would say [that] the other point [is] —and I have no evidence for this, it's just guessing, what I'm about to tell you-I think, at that point, the position of ZANU [Zimbabwe African National Union] was, 'Thank you, but we can handle our problem.' 
Second, on Zimbabwe's abrupt departure in 2003, following the roiling tension in the country, the Commonwealth's critical election observers report, Zimbabwe's partial suspension and the parallel creation of the Troika. The public news story was the progressive breakdown of relations between Mugabe and the Blair government, and Mugabe's hypersensitivity to criticism from the 'old' Commonwealth, typified by Australian Prime Minister John Howard. My interview with P. J. Patterson threw a different light on this-of the Commonwealth working to put supportive systems in place to help Zimbabwe's return to democratic forms and norms. And the hope that 'P. J.', as a long-standing friend of Zimbabwe and personal friend of Mugabe, was the best person to persuade him.

[W] e got along extremely well. He would refer to me always as 'my brother, my brother'. When I knew that what we had worked out in Abuja was going to end up as it did, I remember very well the conversations that were held between President Obasanjo, President Thabo Mbeki and myself with him. We spoke from Abuja by telephone to him in Harare. I knew we were in real trouble after the others had spoken to him and I was to have my turn in speaking to him. Instead of his saying 'my brother', he said, 'Mr Patterson'.

... And I knew that he was really confirming what he had said to Obasanjo and Mbeki: that, if there is going to be a suspension, Zimbabwe no longer has an interest in being a member of that sort of association. (P. J. Patterson, Prime Minister of Jamaica)

\section{Other Issues}

The quotes above are only a small sample from the considerable range of topics and events covered in these interviews, and the material on the Commonwealth's diplomacy since the early 1990s up to the Perth Commonwealth heads meeting in 2011. There is a wealth of information on the Commonwealth and election monitoring since its inception in Zimbabwe in 1980, and the extent to which the Commonwealth blazed the trail in scrutinizing and supporting this element of the democratic process-but interviewees stressed much more needs to be done post elections to underpin these democratic processes and transitions, as the story of the Maldives painfully underlines. Championing small states features strongly_such as McKinnon's account of taking on the unelected bureaucrats of the Organization for Economic Cooperation and Development on tax regimes-although the reflections include 'whether small states themselves are good at using the Commonwealth is another matter'. There is a considerable amount of material on the growing importance and emphasis on human rights since the 1980s, the ways and means that these imperatives can best be achieved. The possibilities and limitations of 'good offices'; the emergence of the Commonwealth Ministerial Action Group (CMAG) and how it operated in the early years, and its shortcomings; and climate change - the Commonwealth initiative leading up to the chaotic Copenhagen summit of 2009 contrasts sharply with the altogether clearer message from Malta to Paris COP21. The unseen, unsung role of the Economics Division as the think tank on development underlines that more needs to be done to highlight this: the supportive role of key Commonwealth heads and Commonwealth Secretariat officials on debt relief and restructuring the international financial system in the late 1990s/early 2000s; the role of women and development; and some-but not enough-detail on the role and importance of the Queen to the association. Remarks from political advisers on the value newly independent heads attached to the Retreat, and the fear some had-expressed by Simon Murdoch—of their prime ministers going 'off piste' without their officials. 
The theme of leadership and varying styles of leadership runs throughout the interviews, giving perspectives on different approaches by high-ranking officials, as well as political leaders themselves - and offering frank insights on whether the Commonwealth was valuable, useful or insignificant in their national view. This is something Commonwealth civil society organizations would do well to remember: their energies as pressure groups need to be directed to individual national governments, or meetings of specific Commonwealth ministers, rather than bleating to the Secretariat to persuade heads to pay attention to their individual agenda. The four surviving former secretaries general interviews with the former secretaries general offer an intimate view of different approaches to management-or lack of it-at the top level of the Secretariat as an international institution. The value of the Commonwealth's variety and multiple networks comes through loud and clear, for information and intelligence, policy leverage and useful contacts. This was underpinned by education and friendships formed at university. For example, S. G. Ramphal was aware of the likelihood of South Africa's acquisition of atomic weapons by 1978, from his regular discussions with the ANC/AAM activist Abdul Minty. I have alluded to the pre-existing contacts between Bob Hawke and Sir William Heseltine; and Chief Emeka's extraordinary political antenna when Secretary General which were enormously admired by his staff. These are just three examples of extraordinary networks of Commonwealth connectivity, and means of engagement.

The interviews also highlight the extent to which the Commonwealth as an association is defined by its leadership to an extraordinary degree. There were repeated illustrations that it requires its Secretary General to be a master of communications and the modern media, to seize every media opportunity to articulate and present a Commonwealth view, however uncomfortable this may be. Unfortunately, these were not the outgoing Secretary General Sharma's strengths. This goes beyond a clearly communicated vision, and for the Secretary General to be proactive and media savvy: the Commonwealth is at its best as a diplomatic actor when it is following 'dual track diplomacy'. The example of Thatcher, the rest of the Commonwealth and pressure for change in South Africa is a case in point. However, with the growing role and 'voice' of civil society since the 1990s, particularly on the question of human rights, this has created rising expectations and demands for action and delivery: that the Secretary General and CMAG should both be vocal in condemnation and be seen to be achieving results to correct 'serious and persistent violations'. This can be a fine diplomatic line to walk, as there are many past instances of recalcitrant Commonwealth heads refusing to see representatives of the Commonwealth, including the Secretary General. Examples in the interviews include former Nigerian dictator Sani Abacha's refusal to allow CMAG into the country, and the events leading up to Zimbabwe's abrupt departure from the Commonwealth at the Abuja CHOGM.

\section{Concluding Observations}

I would like to conclude with some reflections on 'findings' from the Commonwealth's past. As a historian, I am innately suspicious of hard and fast 'lessons' to be learned from past events which then should be applied in the future. But I do think the Commonwealth now would do well to reflect on what has worked well in the past - as well as its limitations - and why this might be. It is not directly associated with the question of limited funding. There is a considerable amount on reforming the Commonwealth, in the four interviews with 
recent members of the EPG 2010-11, former members of CMAG and heads of the Political Affairs Division (particularly, the detailed reflections by Matthew Neuhaus). I do not have to tell this audience that the Commonwealth is particularly and peculiarly defined by the quality of its leadership, and the characteristics of the Secretary General. The interviews make clear to me that Arnold Smith does not get sufficient credit for building up the early Secretariat and his astute use of the policy space the Commonwealth provided to provide capacity and knowledge transfers for newly independent states and their small bureaucracies. Ramphal would not have achieved anything like the impact that he did were it not for the institutional platform created by his predecessor.

There was a particular Cold War/post-colonial moment in international relations for which the association of the Commonwealth was ideal. It was not simply the cause of fighting apartheid, first in Rhodesia and then in South Africa. If Ramphal was the right man for the time, so was Chief Emeka in the immediate post-Cold War world, with the international drive for economic liberalization and democratization, and his own vision of promoting and supporting African democratization and good governance. In the view of a number of the people I have interviewed, he was able to achieve a considerable amount in promoting African democratization precisely because he was a Nigerian. There are perennial sensitivities about external criticism - the choice of special envoys for good offices is as relevant as ever (choosing former coup leader turned democratic politician Sitiveni Rabuka in the Malitai conflict proved highly effective).

When doing these interviews, there was an uncoordinated vow of omission-a nearly uniform refusal to comment on Secretary General Sharma's leadership since 2008-and a deliberate emphasis on a golden past (Ramphal, Anyaoku and 'even' McKinnon) which shouted the sense of disappointment in the present era. The international system and array of diplomatic actors have changed dramatically, while media provision and platforms have exploded. Civil society associations and actors, inputs from business interests, the role of the media, all have greater play in the formulation and presentation of a state's policy. At the Witness Seminar on the history of the Secretariat, Patsy Robertson commented that in the 1980s the Commonwealth had a moral 'good news' story on apartheid, and that the press beat a path to Marlborough House's door. Cheryl Dorall noted the monumental effort devoted to trying to capture the media's attention after 1994. What the Sharma era has underlined is the need for the Secretary General and political affairs to be proactive and immediately responsive, rather than the despair of media and communications; and furthermore, for Marlborough House to shift from the defensive and an obsession with process. The complexity of the challenges facing the international system underlines the centrifugal forces within the Commonwealth. The Commonwealth has been overtaken-overshadowed-by other international summits and international organizations, and regional groupings. For instance, former Deputy Foreign Minister Aziz Pahad confided that the ANC government preferred the South African Development Community because it was smaller, had a regional identity and met more often to discuss issues of immediate and identifiable concern. A number of interviewees referred directly to reorganizing the heads meeting. It is a quintessentially smart power organization-but it does require people to think outside the box. My meeting at the Foreign Office last year was a classic example: I was speaking to the Commonwealth desk officer, outlining what the Institute of Commonwealth Studies (ICWS) could do in terms of knowledge training coming out of this interview project, and said that it should not just be the six members of the Commonwealth team. What of the 
Caribbean desk, the new head of East Africa Division...? That idea really did come out of the clear blue sky for her.

There is a repeated refrain running through the interviews of hopes of what the Commonwealth could achieve, contrasted to complaints of its failings. All said, there is a continued role for the Commonwealth and for the Secretariat. Its informality and humanity remains a trump card. States still need human skill capacity support, legal support dealing with multinational corporations. (The Nobel Prize winner for Economics, Angus Deaton, has recently suggested a reformed World Bank should fulfil this role. The Commonwealth was there first.) The Commonwealth's contribution as a knowledge facilitator-providing the thinking on development and input for the G-20 meetings, which Dr Indrajit Coomaraswamy confirmed has been a deliberate and sustained policy-does not get the exposure it deserves.

In terms of challenges for current Secretary General Patricia Scotland, the interviews underline the need for a clearly communicated vision and clear strategy, with this agenda communicated to staff. Furthermore, on the need to avoid inner circles and coteries and to ensure supporting appointments to complement the particular strengths of the Secretary General, particularly, being proactive and imaginative in terms of the media. In terms of 'cause' focus, adopting a much more public stance on human rights will directly address the debate about a Human Rights Commissioner; and to build in ongoing support mechanisms for democratic transitions, following elections (for example, for the Maldives-as Sir Don McKinnon trenchantly emphasized).

This question of leadership goes beyond the Secretary General, and Marlborough House. It demands the input of heads, and a supporting network of senior officials. For the Commonwealth to work well it needs a core group of heads from the larger powers-who, as David MacDowell put it, 'get' the Commonwealth:

If you don't have a core of five, six, nine, ten ... If there's not that core of heads of governmentof presidents and prime ministers-who actually want to drive it a bit, then it's very hard to make it work. (Max Gaylard, Head, Political Affairs Division, Commonwealth Secretariat)

So the new Secretary General would do well to identify quickly and work particularly with a core group of heads. The regular meetings of ministers of finance, law, education and health are valuable, as are the associate organizations and professional associations. But they are not enough.

What do the interviewees think about the future of the Commonwealth? The jury's out on the future headship and Prince Charles: will it 'unravel like a jersey leaving only Prince Charles at the top?' was how one interviewee put it. The weight of opinion of those interviewed comes down on 'business as usual' after the Queen passes on. As for the future of the association, speaking before the Malta summit, Sir Sonny concluded:

I'm troubled now; it's true-very troubled. I think it has lost its way. I mean, my years, in a sense, were lucky because I had a cause ... I think the Commonwealth could have a cause-could have causes-and fight for them and pursue them, but it seems to have lost [its] fight. So, I am troubled, and the choice of the next Secretary General is going to be absolutely crucial.

The election of a new Dominican/British Secretary General and Britain's offer to host the next CHOGM in 2018 represent an excellent moment for renewal, getting British re-engagement. In Sir Sonny's words, 
My object was to try to get a summit in Malaysia [in 1989] ... I saw the venues as an asset, and that was the asset: to get Mahathir to hold a meeting. Now, here's a great sceptic. He really doesn't believe in it, and I'm telling him, 'I understand all the problems you have with the Commonwealth. Change it. Have a hand in doing something about it, not sulking.'

S. O. [Interviewer]: 'If you want to change [the Commonwealth], get inside and change it'?

'And to do that, you host the summit. You run the summit.' And he did. He rose to the challenge. And then, as it went along, he began to see advantages in hosting the summit. (Sir Sonny Ramphal)

If the Prime Minister and her staff at No 10 are wise, they will emphasise the importance of hosting the next CHOGM to Britain being at the heart of the modern Commonwealth, and start publicly planning it now. 